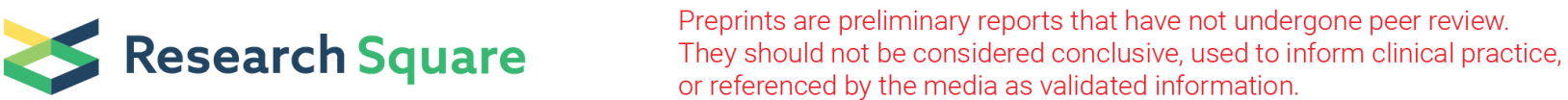 \\ Impact of In-store music on Customers, Owners, and Employees in India
}

Lovish Bandwal ( $\sim$ bandwallovish7@gmail.com )

Department of Design, Indian Institute of Design and Manufacturing Jabalpur, Madhya Pradesh 482005, India

\section{Sarvesh Tripathi}

Department of Design, Indian Institute of Design and Manufacturing Jabalpur, Madhya Pradesh 482005, India

\section{Tripti Singh}

Department of Design, Indian Institute of Design and Manufacturing Jabalpur, Madhya Pradesh 482005, India

\section{Research Article}

Keywords: Music, Retail store, Consumer behaviour, Customer experience, Sales

Posted Date: February 10th, 2022

DOI: https://doi.org/10.21203/rs.3.rs-1308264/v1

License: (c) (1) This work is licensed under a Creative Commons Attribution 4.0 International License. Read Full License 


\section{Abstract}

Music has the power to evoke emotional responses and helps to improve humans mental states. Music is mostly thought of more as an entertainment source but it can also be used to accomplish other objectives like enhancing retail experience, making unity, improving psychological behaviour. Background music played in stores can shape customers' sense of how much time they spend in a store, what to purchase, and how much to spend. In this study, the research was focused on how to enhance the customer music listening experience in retail stores. The multi-brand stores and big retail stores have their own music recommendation from music experts or music managers. In many local stores, owners play songs according to their own mood and liking. The wrong music selection affects the experience of customers and employees.

For this research, fashion retail stores from multi-brand stores to locally-owned shops in Celebration Mall, Udaipur were selected. In the mall, it was observed that out of 30 fashion stores 24 stores were not playing background music. The purpose of this project is to enhance the retail shop experience in Indian stores through the use of music by following user-centric processes and researching all possible solutions to users' needs.

\section{Introduction}

The goal of this study was to see how background music in a retail setting affected the buying behaviour of the Indian audience. Various factors of music were focused like volume, genre, mood, the familiarity of music on customer behaviour. Another aspect of the study was to find out the other factors that are involved in affecting shopping behaviour through music. The current study focuses on the effect of background music on customers in a retail environment. Then, it's critical to consider how music is utilised as an atmosphere. It has been discovered that customers do react psychologically and behaviorally to music, despite the fact that some of the shoppers are conscious of its presence [1]. When Music is used properly in stores, music may have a good effect on customers as they shop. According to Eroglu [2], music may help to mitigate 14 negative impacts associated with crowding in retail contexts.

\section{Music and Retail}

Background music is a mixture of sound that can create a harmonic, united and expressive composition through combinations of beats, rhythm, tempo and timbre [3]. It can refer to various styles and types of music and genres. Background music is generally played on different volumes and its main focus is not to be listened to by the customers or audience. Music is also used in the background of Gyms, offices, and retail stores to produce desired attitudes and behaviours among staff and customers. Background music improves the store environment, makes employees energetic, and stimulates consumer purchasing power [4].

According to Mehrabian and Russell's (M-R) model, people react to their environment in three distinct ways: pleasure, arousal, and dominance [5]. Environmental factors (sights, sounds, odours, etc.) produce 
an emotional reaction (pleasure, arousal, dominance), which eventually results in approaching resistance (spending, exploration, satisfaction, attitudes). According to Donovan and Rossiter [6] Ref it was really hard to quantify emotional reactions to environmental influences. Yalch and Spangenberg (2000) [7] applied a similar concept to music, specifically familiarity in music, and they found that customers purchased for longer periods of time when listening to less familiar music than while listening to more familiar music. Customers were less excited by new music than by familiar music, and they spent more time shopping when exposed to less familiar background music. Herrington and Capella (1996) [8] in their research discovered that a shopper's spending time and money depends upon their liking of background sound.

Vida [9] stated that "Most of the retailers have known the value of creating atmosphere in their store through creating environmental experience but it is currently less known for music but this market is also growing in the retail sector and customer response". When used properly, music can have a good effect on clients while they shop. Vida discovered that merchants who play planned music in the background are evaluated more positively by patrons than retailers who play unplanned music.

\section{Musical Characteristics and Mood}

Bruner [10] discovered that music is a complex collection of controlled factors rather than a simple acoustic mass. Music has a wide range of qualities that come together to form a musical composition and have an emotional impact. Pace, volume, genre, and familiarity are just a few of them. Music has an effect on mood [11], and even a small amount of music has a positive effect on perceived enjoyment. When humans attach non-random emotional meaning to music [12], have non-random affective reactions to music, and then exhibit non-random behavioural responses as a result of music, consumer behaviour occurs.

\section{Effect of Genre, Tempo \& Volume}

In stores to set up the mood and atmosphere, music plays an essential role in influencing customers. The speed of music depends on tempo which can range from very slow to very fast. Specifically, it's the pace, or tempo, of ambient music which will have the foremost significant effect on shoppers. Changing the volume of music can easily alter the mood of listeners. Pop, classical, Bollywood, and western music are all genres. People of various ages prefer certain genres of music over others. Music/density provides the best shopping experiences. Changing the music's volume can easily alter the mood of listeners.

\section{Genre}

There are many types of music, such as pop music, classical, Bollywood and western, and so on, these are classified as genres. People of different ages prefer certain types of music while they dislike other genre music, according to Aylott and Mitchell [13]. As a result of this study they have stated that "One person's music is 15 another people's noise". There has been very little research done on music genres up to this point. On the other hand, Alpert and Alpert [14] discovered that sad music elicited the strongest purchase intentions, outperforming either happy music or silence in the store. 
In Alpert and Alpert 1986 [15] study, it was found out that happy music can create a soothing and happy environment, while sad or low tempo music played in stores can increase the sales of retail stores. Lin and Wu [16] conducted a similar study in which they discovered the opposite of Alpert and Alpert. The sad music played in retail shops brings more negative feelings in shoppers. Buying a card for a friend while a song with the lyrics "Missing You" plays in the background will have a greater impact on their behaviour [17] (Alpert and Alpert, 1989).

Lin and Wu [16], observed that cheerful music induces good induced feelings, and Broekemier [18] discovered that buyers' inclinations to shop are higher when they are exposed to happy music. Lin and Wu [16] discovered that melody music played in stores brought up negative emotions in customers, in contrast to fast music. Alpert and Alpert's study in 1986 and 1988, and Broekemier [18] found good consequences with cheerful music.

\section{Track Tempo}

When compared to music familiarity and loudness, the tempo of a song has a bigger impact on customer emotions [19]. In an experiment conducted in a U.S. supermarket,[20] played various types of background music with varying tempos daily - some fast, others slow. Meanwhile, he tracked the speed of shoppers as they shopped, and recorded the supermarket's total daily profits. Milliman [20] discovered that the speed of instrumental background music has a substantial impact on in-store traffic flow as well as daily total sales volume. According to Milliman research, switching from fast to slow tempo music improved grocery sales volume by $38 \%$.

According to a 1990 collection of Bruner's [21] investigations, slow tempo generates serious, sad, sentimental, calm, and frightening feelings; medium tempo creates magnificent sensations; and fast tempo suggests entertaining, happy, and exciting feelings. According to Eroglu, Machleit, and Chebat [22], slow music/high density and fast music/low density provide the best shopping experiences.

\section{Volume}

Consumers' perceptions of time can be influenced by the volume and tempo of background music in a store. Customers remained in the store longer when the music was played at a slower pace and at a lower volume [12]. According to Herrington and Capella's [8] study, the pace and loudness of background music had no significant impact on the sample of customers' shopping time or buy amount. They observed that shop purchases and sales are not affected by loudness or tempo, but rather by the customers' familiarity with the music.

The volume of music, as well as its loudness or smoothness, might influence customers' feelings while shopping. Different degrees of music volume can elicit a wide range of emotions. Lin and Wu [16] discovered that pleasant emotions were enhanced by moderately lower volume, which resulted in increased time spent, in their investigation of audio impacts on consuming emotion and temporal perception. Smith and Curnow [23] discovered that when loud music was played in a shop setting, sales per minute increased. Consumers' perceptions of time can be influenced by the volume and tempo of 
background music in a store. Customers were perceiving the music for more time when music was played at a higher volume and a fast tempo in their study, so it was less enjoyable and customers were moving fastly [24].

\section{Layering of Atmosphere}

The parallel mixing of multiple atmospherics promotes the concept of layering. Bell and Ternus [25] define layering as the use of multiple sensory elements to create a certain atmosphere for the store environment, including simultaneous applications of sight, hearing, touch, taste, and smell. When all of these aspects are combined, it has an influence on the customers. According to Vida [9], music must blend effectively with other ambient variables of the environment in order to positively influence customers' perceptions of shopping behaviour. To produce a pleasant effect for customers, various ambience components can be considered where music is one of the factors.

In a retail setting, consistency in aroma and music leads to more positive impressions of the store, its merchandise, and the store environment, according to Spangenberg [26]. According to their findings, not every environmental mixture will attract all 13 shoppers. Vendors should utilise environmental cues rather than two contrasting music and fragrance combinations, according to the researchers. Instead of playing non-Christmas music and spreading a Christmas perfume, a store may focus on only one, or maybe the Christmas scent, at this time of year.

Some of the environmental factors, such as a high temperature, unpleasant music, and intense lighting create a negative impact on customers [27]. Furthermore, applying too many noticeable atmospherics at once may have a negative effect on customers, generating stress, headaches, and frustration, leading to their leaving the store before their designated shopping session.

\section{Retail and shopping}

Music is a major component of customer marketing, it can be used as one of the methods to enhance the mood and experience of customers [28]. If the music played in stores is distracting to customers, then customers may be less likely to purchase which contradicts the store's sole purpose of increasing sales. Pleasant and soothing music makes our customers feel at ease and motivates them to stay for long extended hours in shopping malls and stores.

The Indian retail stores are witnessing a rapid change in the market [27]. Bigger companies are focusing on huge Indian middle and upper-class customers with their strategies of retailing and preferences of Indian customers. To attract customers and influence customers buying, environmental cues such as store lighting, background music, colour and visual merchandising are the strongest factors [29] In the organized retail sector like H\&M, Zara in advanced nations, it has been seen that great importance is given to the in-store environment.

Retail store managers, to attract customers' attention, plan and change the physical surroundings of their retail stores [30] and stimulate the store environments termed 'retail experience design'. Retail managers 
seriously look into experimenting on exteriors, interior placements, layouts of stores, displays, background music and human variables to enhance customer experience and they spend more time in stores [31].

Smith and Curnow [32] published the first study on the effect of environmental alteration on customer behaviour. They varied the loudness of background music and studied the influence on shopping duration, total sales, and environmental perceptions. Kotler [33] coined the term "atmospherics," defining it as an effort to create shopping settings that increase the likelihood of purchase through emotional effects on the consumer.

\section{Music and Mood}

Swinyard [34] found links between shopping and mood. His study shows that interested clients in a good mood enjoy a better shopping experience than those in a bad mood. Swinyard [34] claims that concerned shoppers acquire more information and react more strongly to both happy and unpleasant shopping experiences. Consumers with limited engagement were less likely to be affected by mood and were less concerned with overall shopping experience quality.

\section{Familiarity of Music}

People can either recall the music or they have never heard it before. It was solely based on their own personal experiences. Either they have never heard the music before, have heard it before but can't remember it, or they are completely familiar with it. Although it has been proven that one's taste in music is influenced by familiar music [35]. Yalch and Spangenberg [36] discovered that when customers were exposed to strange music, time seemed to slow down. According to Yalch and Spangenberg from a recent study in 2000 , customers were less aroused when listening to unfamiliar music than when listening to recognised music.

Consumer familiarity with the store's background music had a beneficial influence on patronage, according to Garlin and Owen [19]. Consumers are more inclined to shop in new service locations that play the music they like, according to Broeckmeir (2005). According to Garlin and Owen's findings, when familiar music was playing in the store, individuals stayed slightly longer than they would in a similar venue where the music was unfamiliar. According to this study, familiarity with music benefits customers and thus sales.

\section{Objectives}

The purpose of this study is to determine the effect that background music has on the retail manager, customers, and employees. The effect of music's type, familiarity, and volume on the environment of retail stores. Some of the existing research contradicts other claims about tempo and volume. This research will help retail businesses in India in providing a better customer experience.

The main objectives of the research are: To provide knowledge and awareness about music impact to retail store owners, To enhance the customer experience in retail stores and To choose music according to customer base 


\section{Methodology}

\section{Direct Observation}

The main goal of direct observation was to understand the customer base in different types of stores. To get better comparisons various factors were considered in-store like the music system, store lighting, Employee behaviour, size of store, Music genre played, Music platform. The aim of this was to understand how music changes according to the store. To identify the user journey, the ICONIC store, Celebration Mall, Udaipur Fig. 1 was selected, and the employees and customers were observed throughout the day. The aim was to understand their pain points, touchpoints, tasks conducted, and body moments.

\section{Questionnaire}

To get customer feedback about a store experience, the survey questionnaire was carried out through a survey form at the ICONIC store. A playlist of popular and trending songs was created and played in-store through YouTube. Customer feedback was gathered at the end of their purchase. To get the form fill in customer feedback. The survey included both qualitative and quantitative questions. Data including their demographics like name, age, sex and a Likert 5-point scale were used to gather their music and store experience at the store. Additionally, questions about their purchase and time spent in the shop were asked in order to have a better understanding of their behaviour and purchasing pattern while music is played in the store.

\section{Hypothesis generation}

To achieve the study's objectives, a survey was conducted to ICONIC customers to determine their perceptions of the music playing in the store, the amount of time they spent in the store, and their level of familiarity with music while shopping. Further hypotheses were generated to understand the scenario.

\section{Hypothesis 1}

If we play unfamiliar music it increases the customer's time spent.

\section{Hypothesis 2}

If we play unfamiliar music in retail stores then it increases the product purchase as they spend more time in-store.

\section{Results}

\section{Overview}

The first part of the methodology started with a direct observation where 30 stores were observed on the basis of music played in the store. Other findings like store licenses to play songs legally were discovered. 
A customer journey mapping was plotted on the basis of observation. A questionnaire survey was conducted on 40 people at the ICONIC store. On the basis of the interviews with various stakeholders, two personas were created to understand our end user. All gathered information was further analysed using an affinity diagram to determine design directions.

\section{Direct Observation}

The first part of the methodology started with a direct observation which was carried through a store visit in the celebration mall and a total of 30 shops were observed Fig. 2. It was observed that out of 30 stores only 6 stores were playing the background music and 13 stores were having music systems. Only 3 stores had a PPL licence to play music legally in Table 1

Table 1

Factors affecting the environment

\begin{tabular}{|llll|}
\hline Store Observed & Music System & Music Played & Commercial license \\
\hline 30 & 13 & 6 & 3 \\
\hline
\end{tabular}

\section{Customer journey mapping}

A customer journey map is a visual tool used to reveal the affiliations between a user and the various elements of a system in sequential order over a period of time. A user journey map plots users' actions, experiences, channels, and places of interactions along the different stages during the usage of any system. It helps in identifying the pain points and opportunities for improvement. Various issues were identified at different stages of service usage which act as the pain points for the user. 
Table 2

Customer journey mapping

\begin{tabular}{|lllll|}
\hline Stages & Actions & Thoughts & TouchPoint & Emotions \\
\hline $\begin{array}{l}\text { Luggage } \\
\text { Check }\end{array}$ & Security Check & Alert & $\begin{array}{l}\text { Security } \\
\text { staff }\end{array}$ & Medium \\
\hline Entry gate & $\begin{array}{l}\text { Greeted by } \\
\text { attendees }\end{array}$ & $\begin{array}{l}\text { Observe environments, such as } \\
\text { music, aroma, and staff } \\
\text { friendliness }\end{array}$ & Staff & High \\
\hline $\begin{array}{l}\text { Product } \\
\text { search }\end{array}$ & $\begin{array}{l}\text { Attendees ask } \\
\text { customers if they } \\
\text { require any help }\end{array}$ & $\begin{array}{l}\text { Ask staff to help them in finding } \\
\text { a suitable product }\end{array}$ & $\begin{array}{l}\text { Mannequin, } \\
\text { Employees }\end{array}$ & Medium \\
$\begin{array}{l}\text { Approaching } \\
\text { product }\end{array}$ & $\begin{array}{l}\text { Move towards the } \\
\text { particular section/ } \\
\text { Observe here and } \\
\text { there }\end{array}$ & $\begin{array}{l}\text { If music is too loud or } \\
\text { unrelatable, complain. Ads grab } \\
\text { their attention }\end{array}$ & $\begin{array}{l}\text { Lightings, } \\
\text { BG Music }\end{array}$ & Low \\
\hline $\begin{array}{l}\text { Product trial } \\
\text { Select some } \\
\text { products for trial }\end{array}$ & $\begin{array}{l}\text { Customers become irritated by } \\
\text { repetitive music }\end{array}$ & Clothing & Low \\
\hline $\begin{array}{l}\text { Decision } \\
\text { making }\end{array}$ & $\begin{array}{l}\text { Selects the best } \\
\text { one suited to them }\end{array}$ & $\begin{array}{l}\text { Move their legs and hands, as } \\
\text { well as do some dance moves }\end{array}$ & Environment & High \\
\hline $\begin{array}{l}\text { Payment } \\
\text { Employee Pack the } \\
\text { bag }\end{array}$ & $\begin{array}{l}\text { Employee was changing songs, } \\
\text { billing, and packing a bag at the } \\
\text { same time, making customers } \\
\text { irritated. }\end{array}$ & $\begin{array}{l}\text { Billing } \\
\text { counter }\end{array}$ & Low \\
\hline
\end{tabular}

\section{Questionnaire}

The questionnaire survey was conducted on 117 people at the ICONIC store, which was carried out through a survey online form. Below is the analysis of the survey:

\subsubsection{Liking on the genre}

Figure 3 shows that most customers would like to listen to English Hollywood songs in the store despite listening to Bollywood songs. While listening to Bollywood or Hindi songs, most customers feel connected to the emotions of the songs. The lyrics of Hindi songs can be easily interpreted as they are easily recognizable, which distracts the mind. In the case of English songs, most of them are difficult to interpret as the customer then associates with the beats and rhythm of the music. During user observations, it was found that most customers started dancing to the beats even if they were not familiar with the songs.

\subsubsection{Time spent in the store}

Figure 4 indicates that more than half of the participants have spent more than 20 minutes in the store when music was played. According to business owners and employees, if customers spend more time 
then they explore more products. The survey results also show that those who spent more time were unfamiliar with the music and moved slowly in the store compared to those who were familiar with songs. The majority of people who spent more than 20 minutes were unfamiliar with the music. It indicates that time spent is dependent on the familiarity and unfamiliarity of music.

\subsubsection{Familiarity of music}

Figure 5 indicates that more than half of the participants did not know the song name or they had not heard the song before as English songs were played in the store. It was found out that customers unfamiliar with the songs purchased were more comparable to those familiar with the song. This indicates that people spend more time and purchase more when they are unfamiliar with the song compared to familiar songs.

\subsubsection{Products purchased when background music is played}

Figure 6 shows that most customers buy 3-5 products in the store when background music is playing and spend more time exploring new products. The survey results also show that people who bought 1 product do not buy completely consciously, but since they spend more time there due to the ambient and background music factors, they tend to buy the product.

\section{Hypothesis analysis}

This section analyzes the data of survey results that influence customer behaviour and validate the hypothesis with the help of Pearson's chi-square test of independence using SPSS.

\section{Hypothesis 1: If we play unfamiliar music it increases the customer's time spent.}

The research hypothesis objective was to verify if there was any association between unfamiliar music and time spent.

\section{Table 3 Chi-square test}

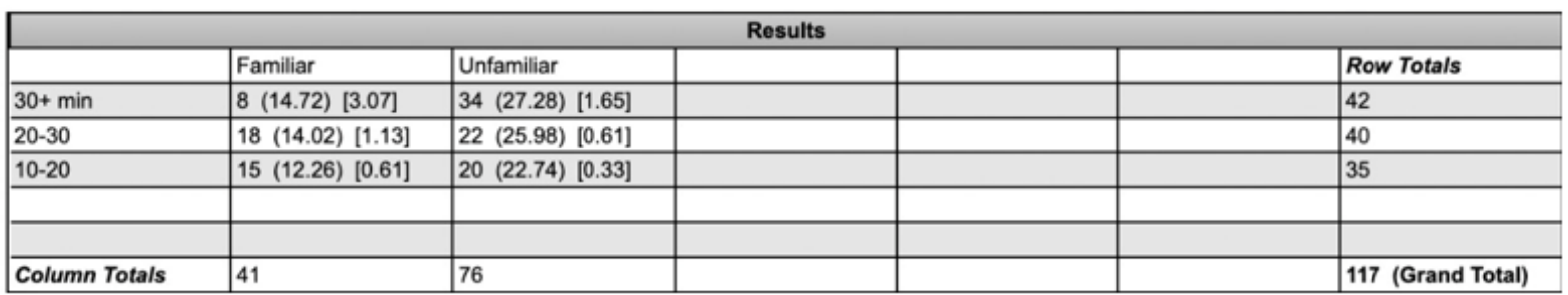

A chi-square test of independence was performed to examine the relation between time spent and the familiarity of songs. The relation between these variables was significant, $X 2(1, N=117)=7.4018, p=$ .024701 . The $p$-value is .024701 . The result is significant at $p<.05$. The results indicate that there is an association between unfamiliar music and time spent. 
Hypothesis 2: If we play unfamiliar music in retail stores then it increases the product purchase as they spend more time in-store.

The research hypothesis objective was to verify if there was any association between unfamiliar music and product purchase as they spend more time in-store

\section{Table 4 Chi-square test}

\begin{tabular}{|l|l|l|l|l|l|l}
\hline \multicolumn{7}{|c}{ Results } \\
\hline & 0 & $1-2$ & $3-5$ & $5+$ & \\
\hline $30+\min$ & $2(5.03)[1.82]$ & $18(16.87)[0.08]$ & $10(13.64)[0.97]$ & $12(6.46)[4.75]$ & \\
\hline $20-30$ & $4(4.79)[0.13]$ & $14(16.07)[0.27]$ & $17(12.99)[1.24]$ & $5(6.15)[0.22]$ & \\
\hline $10-20$ & $8(4.19)[3.47]$ & $15(14.06)[0.06]$ & $11(11.37)[0.01]$ & $1(5.38)[3.57]$ & & 42 \\
\hline & & & & & & \\
\hline & & & & & 18 & \\
\hline Column Totals & 14 & 47 & 38 & & \\
\hline
\end{tabular}

A chi-square test of independence was performed to examine the relationship between product purchase and the time spent in-store while unfamiliar music is played. The relation between these variables was significant, $X 2(1, N=117)=16.5795, p=.01096$.

The results indicate that there is an association between unfamiliar music and product purchase. Also, in the $\mathrm{H} 1$ it was found that playing unfamiliar music increased the customer's time spent. By combining both the results it is evident that playing unfamiliar music in stores increases the product purchase as customers spend more time in-store.

\section{Conclusion}

Firstly, the status of stores was identified in terms of playing music and using licensed music in their stores. This finding shows that store owners are not aware of the impact background music has on customers and staff and how it contributes to sales and customer dwell time. Awareness of commercial licensing is also not present, which shows that they do not support music producers.

According to the interview findings, music should be unique give the brand a distinctive image and fit the profile of the business. Music is also a key factor in deciding whether the brand is desirable or not. Music creates brand identity and uniqueness for their brand so that it reduces the uncertainty about the brand image among new customers.

The volume of music can harm the customers and make them leave the store. To create a better environment, the volume should be optimal for all age groups. Music that does not match the store can make customers feel uncomfortable, leave or not enter the store. More importantly, it was recognized that the impact of such problems on brand image and the store itself. One of these problems was song selection for the store, which can be solved with the help of music experts. Music experts can analyze the store according to the store size, customer base, and type of products and recommend a better-licensed playlist for your store. 
Familiarity and unfamiliarity with music play a major role. Unfamiliar songs tend to make customers spend more time and buy more products as compared to familiar songs. To create a better playlist, focus on the customer base and their demographics, so proper playlist creation would help store owners improve customer and employee experience, increase sales and decrease customer retention.

This research adds to our knowledge of consumer behaviour, particularly as it relates to background music and customers. Managers should be aware of the findings and use them to enhance profits in their stores. Music familiarity affects a customer's mood while buying. Managers should play the music that is familiar to this type of consumer to create a friendly atmosphere. This will improve the customer's attitude and overall purchasing experience.

While the management cannot control the customer's attitude before they visit the shop, there are actions that may be performed to generate a happy atmosphere. The store's exterior and window displays will provide a lasting first impression. If a consumer sees a tidy storefront before entering, their attitude may improve. Also, audio speakers should be positioned at the store's door so visitors can hear the music inside. The right music may boost a store's vibe and attract consumers. If managers can take advantage of this opportunity, and consumers are happy as they enter the store, they are likely to have a nice shopping experience. To keep customers happy, shop employees must welcome them and deliver excellent customer service.

Managers must ensure that many aspects of their store's atmosphere are pleasing to the client. The survey found that the better the entire shopping experience, the happier the consumers. Finally, through analysis, an application was designed and developed. The personalised playlist gives a better user experience to the users.

\section{References}

1. Yalch, R. and Spangenberg, E. (1990). Effects of store music on shopping behavior. Journal of Consumer Marketing, 7(2), 55-63.

2. Eroglu, S., Machleit, K., and Chebat, J. (2005). The interaction of retail density and music tempo: Effects on shopper responses.

3. A. Fernández-Sotos, A. Fernández-Caballero, and J. M. Latorre, "Influence of tempo and rhythmic unit in musical emotion regulation," Front. Comput. Neurosci., vol. 10, no. AUG, p. 80, Aug. 2016.

4. G. Mohan, B. Sivakumaran, and P. Sharma, "Impact of store environment on impulse buying behavior," Eur. J. Mark., vol. 47, no. 10, pp. 1711-1732, Sep. 2013.

5. Mehrabian A, Russell JA. The Basic Emotional Impact of Environments. Perceptual and Motor Skills. 1974;38(1):283-301.

6. Donovan, R. J. and Rossiter, J. (1982). Store atmosphere: An environmental psychology approach. Journal of Retailing, 58(Spring), 34-57. 
7. R. F. Yalch and E. R. Spangenberg, "The Effects of Music in a Retail Setting on Real and Perceived Shopping Times,” J. Bus. Res., vol. 49, no. 2, pp. 139-147, Aug. 2000.

8. Herrington, J. and Capella, L. (1996). Effects of music in service environments: A field study. Journal of Services Marketing, 10(2), 26-41.

9. Vida, Irena. (2008). The impact of atmospherics on consumer behaviour: The case of the music fit in retail stores. Economic and Business Review for Central and South-Eastern Europe, 10(1), 21-35.

10. Bruner, G. C. (1990). Music, mood, and marketing. Journal of Marketing, 54(4), 94- 104.

11. Coloma, D., and Kleiner, B. (2005). How can music be used in business? Management Research News, 28(11/12), 115-120.

12. Garlin, F. and Owen, K. (2006). Setting the tone with the tune: A meta-analytic review of the effects of background music in retail settings. Journal of Business Research, 59, 755-764.

13. Aylott, R., and Mitchell, V. (1998). An exploratory study of grocery shopping stressors. International Journal of Retail \& Distribution Management, 26(9), 362-373.

14. Alpert, J. and Alpert, M. (1988). Background music as an influence in consumer mood and advertising responses. Advances in Consumer Research, 16, 485-491.

15. Alpert, J. and Alpert, M. (1986). The effects of music in advertising on mood and purchase intentions. Unpublished working paper 85/86, 5-4, University of Texas, Austin.

16. Lin, C., and Wu, S. (2006). Influence of audio effects on consumption emotion and temporal perception. Journal of American Academy of Business, 10(1), 174-178.

17. Alpert, J. and Alpert, M. (1989). Background music as an influence on consumer mood and advertising responses. Advances in Consumer Research, 16, 485-493.

18. Broekemier, G., Marquardt, R., and Gentry, J. (2008). An exploration of happy/sad and liked/disliked music effects on shopping intentions in a woman's clothing store service setting. Journal of Services Marketing, 22(1), 59-67

19. F. V. Garlin and K. Owen, "Setting the tone with the tune: A meta-analytic review of the effects of background music in retail settings," J. Bus. Res., vol. 59, no. 6, pp. 755-764, Jun. 2006.

20. Milliman, R. (1982). Using background music to affect the behavior of supermarket shoppers. Journal of Marketing, 46, 86-91.

21. Bruner, G. C. (1990). Music, mood, and marketing. Journal of Marketing, 54(4), 94- 104.

22. Eroglu, S., Machleit, K., and Chebat, J. (2005). The interaction of retail density and music tempo: Effects on shopper responses. Psychology \& Marketing, 22(7), 577-589.

23. Smith, P.C. and Curnow, R. (1966). Arousal hypotheses and the effects of music on purchasing behavior. Journal of Applied Psychology.

24. Bailey, N. and Areni, C. (2006). When do a few minutes sound like a lifetime: does atmospheric music expand or contract perceived time? Journal of Retailing, 82(3), 189-202.

25. Bell, J. and Ternus, K. (2002). Silent selling: Best practices and effective strategies in visual merchandising (2nd ed.). New York, NY: Fairchild Publications, Inc. 
26. Spangenberg, E., Grohmann, B., and Sprott, D. (2005). It's beginning to smell (and sound) a lot like Christmas: The interactive effects of ambient scent and music in a retail setting. Journal of Business Research.

27. R. Aylott and V. W. Mitchell, "An exploratory study of grocery shopping stressors," Br. Food J., vol. 101, no. 9, pp. 683-700, Oct. 1999.

28. J. A. Russell and A. Mehrabian, "Distinguishing anger and anxiety in terms of emotional response factors," J. Consult. Clin. Psychol., vol. 42, no. 1, pp. 79-83, Feb. 1974.

29. "RETAILING: TRENDS IN THE NEW MILLENNIUM - R. Shanthi, M. Rafeeque Ahmed, S. Gurusamy, P. Murari - Google Books."

30. L. W. Turley and J.-C. Chebat, "Linking Retail Strategy, Atmospheric Design and Shopping Behaviour," vol. 18, no. 1-2, pp. 125-144, Feb. 2010.

31. R. E. Milliman, "Using Background Music to Affect the Behavior of Supermarket Shoppers:," vol. 46, no. 3, pp. 86-91, Nov. 2018.

32. Smith, P.C. and Curnow, R. (1966). Arousal hypotheses and the effects of music on purchasing behaviour. Journal of Applied Psychology, 50(3), 255-256.

33. Kotler, P. (1973-1974). Atmospherics as a marketing tool. Journal of Retailing, 49, 40- 64.

34. W. R. Swinyard, "The Effects of Mood, Involvement, and Quality of Store Experience on Shopping Intentions," J. Consum. Res., vol. 20, no. 2, pp. 271-280, Sep. 1993.

35. Davies, J. (1991). The musical mind. New Scientist, 129, 38-41.

36. Yalch, R. and Spangenberg, E. (1988). An environmental psychological study of foreground and background music as retail atmospheric factors. In A. W. Walle (Ed.), AMA Educators Conference Proceedings (pp. 106-110). Chicago: American Marketing Association.

\section{Declarations}

Competing interests:

The authors declare no competing interests.

\section{Figures}

\section{Figure 1}

ICONIC store in the Celebration mall 
Direct observation on users and employee

Figure 3

Music categories

Figure 4

Time spent in the store

Figure 5

Familiarity of music

Figure 6

Product purchased 